Acta vet. scand. $1976,17,25-31$.

From the Odense Municipal Laboratory for Environmental and Food Examinations, Odense, Denmark.

\title{
A COMPARISON OF SEITZ AND MILLIPORE MEMBRANE FILTERS FOR THE ENUMERATION OF FECAL COLIFORMS
}

\author{
By \\ Henry Sфgaard
}

SØGAARD, HENRY: A comparison of Seitz and Millipore membrane filters for the enumeration of fecal coliforms. Acta vet. scand. $1976,17,25-31$. - In a comparison of two commonly used membrane filters for emunerating fecal coliform bacteria it was demonstrated that Seitz type M filters recovered statistically more colonies of bacteria than did Millipore HAWG 047S1 filters from pure cultures of Escherichia coli incubated at $44^{\circ} \mathrm{C}$. The membranes were grown on $0.4 \%$ Teepol agar. On incubation at $37^{\circ} \mathrm{C}$ no significant discrepancy was found. As a reference method was used pour plating in plate count agar (Difco). It was demonstrated that incubation at $44^{\circ} \mathrm{C}$ did not per se inhibit propagation of fecal coliforms. Both types of filters examined were sterilized by the manufacturers with ethylene oxide. The discrepancy found can therefore not be due to sterilization procedures.

membrane filtration; fecal coliforms.

Detection of Escherichia coli is the method most commonly applied for the demonstration of fecal pollution of water samples. The bacteriological procedures usually include a quantitative determination of such organisms. According to the official Danish standard methods for examination of drinking water, which were published in 1974 (Vandundersфgelse), fecal coliform bacteria may be enumerated by two different methods: A most probable number procedure using MacConkey broth or Gray's glutamic acid medium, or by membrane filtration. After filtration, the membranes are transferred to Teepol agar or to filter paper pads soaked with Teepol broth.

The standard methods do not specify which commercial brand or type of membrane filters should be used. Presswood \& 
Brown (1973) demonstrated that one commercial brand of filters recovered statistically more colonies of bacteria from pure cultures of $\mathrm{E}$. coli than did another one. This discrepancy could be demonstrated at either $35^{\circ} \mathrm{C}$ or $44.5^{\circ} \mathrm{C}$.

In our laboratory we therefore decided to make a comparative study of the two commercial brands of membrane filters which we use. The study was designed to produce a number of data sufficient for a statistical analysis. Pure cultures of E. coli strains were studied and the filtens were incubated at $37^{\circ} \mathrm{C}$ and $44^{\circ} \mathrm{C}$ parallelly. As a method of reference was used pour plating.

It should be emphasized that other commercial brands of membrane filters are available in the market. The results of the present study, therefore, do not indicate which brand is the one of choice.

\section{MATERIALS AND METHODS}

\section{Bacterial strains}

A total of 20 strains of Escherichia coli were included in the study. They were all isolated from drinking water samples. The identity of the strains were established according to typical reactions in the following tests: growth in semi-solid agar, VogesProskauer reaction, indole production, fermentation of glucose and malonate, gelatin liquefaction, $\mathrm{H}_{2} \mathrm{~S}$-production. Media used for these tests were as described by Lautrop (1956). Furthermore, determination of lysin and ornithine decarboxylase was done according to Mфller (1955).

\section{Membrane filters}

The following two commercial brands of $0.45 \mu \mathrm{m}$ porosity membrane filters were compared: Millipore, HAWG 047S1 (Millipore Corporation, Bedford, Massachusetts 01730, USA) and Seitz type M, catalogue no. 004510474211 (Seitz-Asbest-Werke, Theo u. Geo Seitz, Bad Kreuznach, Germany). Both brands of filters are made from mixed esters of cellulose and they are sterilized by the manufacturers with ethylene oxide. The same lot of the two filters were used throughout the study.

\section{Preparation of bacterial suspensions}

The strains were grown overnight in nutrient broth (Difco) at $37^{\circ} \mathrm{C}$. In the following morning fresh broth was inoculated 
from these cultures. The cell density was followed in a spectrophotometer (Spectronic 20) at $450 \mathrm{~nm}$. Incubation was interrupted at O.D. 1.0 which corresponded to an approximate cell concentration of $10^{8}$ per ml. From the cultures, ten-fold dilutions were made in quarter strength Ringer solution. Two 1 of $10^{-8}$ dilution were made by adding $20 \mathrm{ml}$ of $10^{-6}$ dilution to $1980 \mathrm{ml}$ of Ringer solution. The final suspension thus contained a concentration of cells within a workable range for membrane filtration, i. e. approx. $10^{2}$ per $100 \mathrm{ml}$.

\section{Procedures}

From each of the cell suspensions 20 replicate cultures were prepared on Millipore filters, and 20 on Seitz filters. Fifty $\mathrm{ml}$ were filtered through each filter by use of a Millipore filtering apparatus. The filters were transferred to Teepol agar plates. Of the replicate samples half were incubated at $37^{\circ} \mathrm{C}$ and half at $44^{\circ} \mathrm{C}$ for $24 \mathrm{hrs}$. After incubation the number of colonies were counted under a stereo-microscope at a $7 \times$ magnification.

For pour plates, six replicate samples were made in plate count agar (Difco). Of these, three were incubated overnight at $37^{\circ} \mathrm{C}$ and three at $44^{\circ} \mathrm{C}$. Number of colonies were counted in a Quebec colony counter.

\section{RESULTS}

A mean value was calculated from all lots of replicate samples. These data are presented in Table 1. Results from pour plating represent the number of colony forming units per ml of the $10^{-6}$ dilutions whereas figures from membrane filters are derived from $50 \mathrm{ml}$ of $10^{-8}$ dilutions.

In paired experiments, the differences of two partners receiving two kinds of treatment can be assumed to be normally distributed. The differences can therefore be applied to a t-test by using the following equation:

$$
t=\frac{\bar{d}}{s_{d} / \sqrt{n}},
$$

where $\bar{d}$ is the mean of the differences between paired lots of replicate samples, $s_{d}$ is the standard deviation, and $n$ is the number of paired experiments. 
T a b l e 1. Mean counts of 10 replicates on membrane filters and three replicates by plate counts of 20 strains of Escherichia coli.

\begin{tabular}{|c|c|c|c|c|c|c|}
\hline \multirow[b]{2}{*}{$\begin{array}{l}\text { E. coli } \\
\text { strain no. }\end{array}$} & \multicolumn{3}{|c|}{$37^{\circ} \mathrm{C}$} & \multicolumn{3}{|c|}{$44^{\circ} \mathrm{C}$} \\
\hline & $\begin{array}{l}\text { Plate } \\
\text { count }\end{array}$ & $\begin{array}{c}\text { Milli- } \\
\text { pore }\end{array}$ & Seitz & $\begin{array}{l}\text { Plate } \\
\text { count }\end{array}$ & $\begin{array}{c}\text { Milli- } \\
\text { pore }\end{array}$ & Seitz \\
\hline 1 & 176 & 60 & 70 & 132 & 67 & 82 \\
\hline 2 & 393 & 134 & 110 & 352 & 87 & 131 \\
\hline 3 & 372 & 139 & 154 & 358 & 148 & 169 \\
\hline 4 & 293 & 93 & 101 & 222 & 100 & 108 \\
\hline 5 & 325 & 179 & 179 & 282 & 168 & 190 \\
\hline 6 & 280 & 137 & 132 & 264 & 119 & 148 \\
\hline 7 & 295 & 139 & 136 & 284 & 146 & 154 \\
\hline 8 & 181 & 47 & 45 & 182 & 53 & 47 \\
\hline 9 & 133 & 38 & 40 & 130 & 41 & 40 \\
\hline 10 & 255 & 92 & 115 & 271 & 100 & 102 \\
\hline 11 & 244 & 86 & 97 & 251 & 91 & 107 \\
\hline 12 & 198 & 94 & 111 & 205 & 93 & 116 \\
\hline 13 & 216 & 68 & 91 & 222 & 70 & 87 \\
\hline 14 & 165 & 68 & 76 & 169 & 64 & 77 \\
\hline 15 & 342 & 118 & 137 & 345 & 114 & 135 \\
\hline 16 & 324 & 151 & 164 & 317 & 148 & 163 \\
\hline 17 & 240 & 74 & 71 & 235 & 77 & 76 \\
\hline 18 & 277 & 118 & 110 & 261 & 115 & 112 \\
\hline 19 & 292 & 135 & 133 & 277 & 135 & 134 \\
\hline 20 & 249 & 100 & 95 & 263 & 86 & 94 \\
\hline Average & 263 & 104 & 108 & 251 & 101 & 114 \\
\hline
\end{tabular}

In Table 2 a summary is given of comparisons between the various methods which were tested. Since figures from membrane filtrations and pour plates are based on different dilutions, no direct comparison has been made between these procedures. The results given in Table 1, however, indicate that the number of colony forming units seems to be somewhat less when determined by the membrane filtration procedures. Pour plates were included in the study in order to assess whether an incubation temperature of $44^{\circ} \mathrm{C}$ per se had a detrimental effect on the growth capacity of $\mathbf{E}$. coli. According to Table 2, this apparently is not the case. On a selective medium like Teepol agar, $44^{\circ} \mathrm{C}$ does not inhibit E. coli cells in the logarithmic growth phase to a significant degree. This can be seen by comparing results for identical filters at two temperatures. Likewise, no discrepancy 
T a b l e 2. Summary of statistical analyses of the differences between methods for enumeration of fecal coliforms.

\begin{tabular}{lc}
\hline & t-value \\
\hline Plate count $37^{\circ} \mathrm{C}$ vs Plate count $44^{\circ} \mathrm{C}$ & 2.20 \\
Millipore $37^{\circ} \mathrm{C}$ vs Millipore $44^{\circ} \mathrm{C}$ & 0.91 \\
Seitz $37^{\circ} \mathrm{C}$ vs Seitz $44^{\circ} \mathrm{C}$ & 2.73 \\
Millipore $37^{\circ} \mathrm{C}$ vs Seitz $37^{\circ} \mathrm{C}$ & 2.01 \\
Millipore $44^{\circ} \mathrm{C}$ vs Seitz $44^{\circ} \mathrm{C}$ & 4.47 \\
\hline
\end{tabular}

was demonstrable when comparing the efficiency of Millipore and Seitz filters at $37^{\circ} \mathrm{C}$. A statistically highly significant discrepancy, however, was in evidence when the two brands of filters were compared at $44^{\circ} \mathrm{C}(\mathrm{t}=4.47, \mathrm{P}<0.001)$.

\section{DISCUSSION}

Membrane filtration as a method for enumeration of coliforms and fecal coliform in drinking water offers several advantages when compared to MPN-methods. Bacteria can be concentrated from larger samples. It is less labor consuming, which increases the capacity of a routine laboratory. Furthermore, results are available in a shorter time. The main objection which can be raised against membrane filtration is that gas production is not detectable. This may necessitate confirmatory steps.

Whereas MPN-methods are well established in Danish laboratories, little experience is available as regards membrane filtration. In our laboratory we have therefore initiated preliminary work in order to gain some experience. The present study is part of this work. The data presented, clearly indicate that two commercial brands may differ in their capacity to recover fecal coliforms. In a similar investigation, Presswood \& Brown (1973) arrived at the same conclusion. They compared Gelman and Millipore membrane filters and found that Gelman GN-6 filters recovered statistically more colonies from pure cultures of $\mathbf{E}$. coli than did Millipore HAWG 047SO filters. This difference was demonstrated at either $35^{\circ} \mathrm{C}$ or $44.5^{\circ} \mathrm{C}$. Comparative examinations of river water for fecal coliforms gave results comparable to those obtained for pure cultures. Schaeffer et al. (1974) also examined natural samples and found no significant differences in the efficiency of the recovery of fecal coliforms on Gelman 
or Millipore filters. However, higher counts of total coliforms were obtained with Gelman filters.

Presswood \& Brown suggested that different methods of sterilization of the filters could be the reason for the difference in the extent of effects on the growth of bacteria.

Dutka et al. (1974) compared autoclave- and ethylene oxidesterilized membrane filters manufactured by Gelman, Millipore, and Sartorius. Their studies indicated that the various brands differed as regards recovery of total coliforms, fecal coliforms, fecal streptococci, and heterotrophs. In general, ethylene oxidesterilized filters were less efficient than those sterilized by autoclave. Sladek et al. (1975) demonstrated that the morphological structure of the filter material was a critical factor. The surface opening diameter seems to be a primary determinant of fecal coliform growth on membrane filters.

The present study supports the view that the method of sterilization is not the crucial factor determining differences between filters of different origins, since the two brands which have been compared were both sterilized by ethylene oxide. The study has also confirmed that selecting membrane filters from a variety of brands which are commercially available should be done with some criticism.

\section{ACKNOWLEDGEMENT}

The author wants to thank Mrs. Jytte Kristiansen for her enthusiastic assistance in planning and performing the technical work.

\section{REFERENCES}

Dutka, B. J., M. J. Jackson \& J. B. Bell: Comparison of autoclave and ethylene oxide-sterilized membrane filters used in water quality studies. Appl. Microbiol. 1974, 28, 474-480.

Lautrop, H.: Gelatin-liquefying Klebsiella strains (Bacterium oxytocum Flügge). Acta path. microbiol. scand. 1956, 39, 375-384.

Møller, V.: Simplified tests for some amino acid decarboxylases and the arginine dihydrolase system. Acta path. microbiol. scand. $1955,36,158-172$.

Presswood, W. G. \& L. R. Brown: Comparison of Gelman and Millipore membrane filters for enumerating fecal coliform bacteria. Appl. Microbiol. 1973, 26, 332-336.

Schaeffer, D. J., Maxine C. Long \& K. G. Janardan: Statistical analysis of the recovery of coliform organisms on Gelman and Millipore membrane filters. Appl. Microbiol. 1974, 28, 605-607. 
Sladek, K. J., R. V. Suslavich, B. I. Sohn \& F. W. Dawson: Optimum membrane structures for growth of coliform and fecal coliform organisms. Appl. Microbiol. 1975, 30, 685-691.

Vandunders $\emptyset$ gelse. Udvidet bakteriologisk drikkevandsunders $\varnothing$ gelse. (Examination of water. Advanced bacteriological drinking water examination). Dansk Standard 265.1. June 1974.

\section{SAMMENDRAG}

En sammenligning af Seitz og Millipore membranfiltre til påvisning af fækale kolibakterier.

To almindeligt anvendte membranfiltre til bestemmelse af fækale kolibakterier i vand blev sammenlignet. Det er påvist, at Seitz type M filtre gav vækst af et statistisk sikkert højere antal bakteriekolonier fra renkulturer af Escherichia coli ved $44^{\circ} \mathrm{C}$. Membranfiltrene blev dyrket på $0,4 \%$ Teepol agar. Ved $37^{\circ} \mathrm{C}$ kunne ikke påvises statistisk signifikante forskelle. Som referencemetode er anvendt kimtælling i plate count agar (Difco). Det kunne vises, at en dyrkningstemperatur på $44^{\circ} \mathrm{C}$ ikke i sig selv hæmmede væksten af E. coli. Begge typer af filtre er steriliseret af fremstillerne med ethylenoxid. Den fundne forskel kan derfor ikke tilskrives steriliseringsprocedurer.

(Received December 12, 1975).

Reprints may be requested from: Henry Sфgaard, Odense Municipal Laboratory for Environmental and Food Examinations, Rugaardsvej 60, DK-5000 Odense, Denmark. 